in braces, the products of the photoinduced reaction or of external current flow, is

$$
\left.\mathrm{Pt} \mid \mathrm{Fe}^{\mathrm{II}},\left\{\mathrm{Fe}^{\mathrm{III}}(\mathrm{LHS})\right\},\right]^{\text {Dye, }},\left\{\mathrm{Dye}^{-}\right\} \quad \vdots \quad \mathrm{Dye}, \mathrm{Fe}^{\mathrm{II}},\left\{\mathrm{Fe}^{\mathrm{III}}(\mathrm{RHS})\right\} \mid \mathrm{Pt}
$$

Photoexcited dye oxidizes iron (II) to $\mathrm{Fe}^{\mathrm{III}}$ (LHS), and power output is governed by a competition of the extent to which the reduced dye $\left\{\mathrm{Dye}^{-}\right\}$is oxidized at the junction by the $\mathrm{Fe}^{\mathrm{III}}$ (RHS) (produced at the right by external current flow), against oxidation by $\mathrm{Fe}^{\mathrm{III}}$ (LHS) (produced locally). The electrodereaction rate will also in general be partly current determining, but here $\mathrm{Fe}^{\mathrm{III}}+\mathrm{e}_{\mathrm{pt}_{\mathrm{t}}} \rightleftarrows \mathrm{Fe}^{\mathrm{II}}$ is fortunately fast; Pt foil $1 \mathrm{~cm}^{2}$ was used. In a series of trials the maximum current output was obtained in the presence of $\mathrm{KH}_{2} \mathrm{PO}_{4}, 0.2 \mathrm{M}$, with $0.27 \mathrm{M}$ $\mathrm{FeSO}_{4}, 0.13 \mathrm{M} \mathrm{H}_{2} \mathrm{SO}_{4}$ and $2 \times 10^{-3} \mathrm{M}$ methylene blue. This solution was used for a detailed investigation of the cell's behaviour under load. The resistance across the cell was varied from $11 \mathrm{k} \Omega$ to $2 \Omega$ and the potential $V$ measured. A graph of $\log \left(V^{-1}-V_{0}^{-1}\right)$, where $V_{0}$ is the extrapolated open circuit potential (e.m.f.) of $27.2 \mathrm{mV}$, against $\log R$, where $R$ is the value of the external resistance, gives a notably straight line over the entire range of values (Fig. 1). This corresponds to an internal resistance in the cell of $3.1 \mathrm{k} \Omega$, which with the e.m.f. of $27.2 \mathrm{mV}$ gives a maximum usable power of $6 \times 10^{-7} \mathrm{~W}$. With no dye there was no photo-e.m.f., and thionine was found to be inferior to methylene blue. Magnetic stirring, and also the use of a rotating wire electrode, diminished the photocurrent.

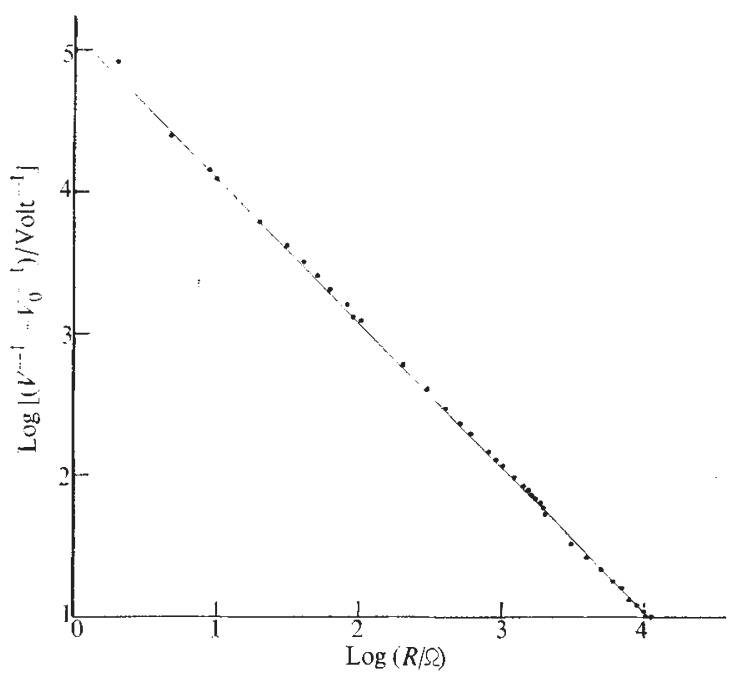

Fig. $1 \log \left[\left(V^{-1}-V_{0}^{-1}\right) /\right.$ Volt $\left.^{-1}\right]$ against $\log (R / \Omega)$ for performance under load $R$ of the photogalvanic cell.

The power output compares favourably with the organic pn semiconductor values ${ }^{1}, 2 \times 10^{-8}$ to $6 \times 10^{-10} \mathrm{~W}$. An illuminated $\mathbf{P t}|\mathbf{S}| \mathrm{KCNS}(\mathbf{l})$ system has been found to give a similar output ${ }^{4}$, and an illuminated $\mathrm{TiO}_{2}$ semiconductor electrode is reported to give about $1 \mathrm{~mA}$ at $0.5 \mathrm{~V}$ (ref. 5), but both are in essence chemical-consuming galvanic cells that are photocatalysed; the latter is indeed potentially useful. Dye-containing photogalvanic cells clearly offer prospects of improvement for example in cell geometry (the $\mathrm{H}$ shape is markedly better than the same illuminatory and electrode configuration in a cylinder), in electro and photoactive species, electrolyte composition, and further parameters.
R. A. HANN
G. READ
D. R. ROSSEINSKY
P. WASSELL

Received June 11, 1973.

1 Meier, H., Albrecht, W., and Tschirwitz, U., Angew. Chem., 11, 1051 (1972).

2 Somer, G., and Green, M. E., Photochem. Photobiol., 17, 179 (1973).

${ }^{3}$ Rabinowitch, E., J. chem. Phys., 8, 560 (1940).

4 Pucciarelli, F., Cescon, P., Diomedi-Camassei, F., and Heyrovsky, M., Chem. Commun., 154 (1973).

${ }^{5}$ Fujishima, A., and Honda, K., Nature, 238, 38 (1973).

\section{Detection of RY Scuti at Radio Frequencies}

IN Table 1 of a previous article ${ }^{1}$ we gave the intensity of RY Scuti on February 21, 1973, 1400 UT as $102 \pm 10$ m.f.u. This should have read $204 \pm 18 \mathrm{~m}$.f.u. The statement that RY Scuti showed variability was intended to imply a possible variability of up to $\pm 25 \%$, not of more than $50 \%$ as implied by the value printed.

V. A. Hughes

A. WOODSWORTH

Astronomy Group,

Department of Physics,

Queen's University at Kingston, Ontario

Received June 8, 1973.

${ }^{1}$ Hughes, V. A., and Woodsworth, A., Nature phys. Sci., 242, 116 (1973).

Editorial, Advertising and Publishing Offices of NATURE

MACMILLAN JOURNALS LIMITED 4 LITTLE ESSEX STREET, LONDON WC2R 3LF

Telephone Number: 01-836 6633. Telegrams: Phusis London WC2R 3LF Telex 262024

MACMILLAN JOURNALS LIMITED

711 NATIONAL PRESS BUILDING WASHINGTON DC 20004

Telephone Number : 202-737 2355. Telex 64280

\author{
Advertisement Department \\ MACMILLAN JOURNALS LIMITED \\ 4 LITTLE ESSEX STREET, LONDON WC2R 3LF \\ Telephone Numbers: UK 01-836 6633. USA 202-737 2355
}

Subscription Department

MACMILLAN JOURNALS LIMITED

BRUNEL ROAD, BASINGSTOKE, HANTS

Telephone Number: Basingstoke 29242

Classified advertisements

T. G. SCOTT \& SON, LIMITED

1 CLEMENT'S INN, LONDON WC2A 2ED

Telephone Number: 01-242 6264/01-405 4743

Telegrams: Textualist London WC2A 2ED

Registered as a newspaper at the Post Office 